\title{
1 Motives for migrating among youth in Russian Arctic industrial cities
}

\author{
Anna Simakova, Maria Pitukhina and \\ Aytalina Ivanova
}

\section{Introduction: youth in the urban Russian Arctic}

The Russian Arctic is strategically important for the country's development, as most of the natural resources that fuel the economy are located there. However, despite its strategic status, the Russian Arctic is characterized by a sharp asymmetry in social and economic development: the region encompasses some of the country's economically most advanced territories as well as some of its most depressed.

The share of youth is lower in the Russian Arctic (13.4\%) than the Russian average (19\%). The Russian government has recently agreed on an ambitious strategy with development goals for the Russian Arctic (Russian Federation, President 2020). According to the document, the achievement of the strategic goals will require both the retention of young people in the Arctic and attracting others from elsewhere in the country. The demographic indicators in Arctic regions show a steady downward trend in the population for the period until 2035 due to a decrease in fertility, an increase in childbearing age and a decrease in the number of marriages. This situation is further aggravated by youth outmigration. According to the strategy, 200,000 new jobs will be created in the Russian Arctic by 2035, particularly in the Yamal-Nenets Autonomous District, Krasnoyarsk Territory, and the Murmansk and Arkhangelsk Regions (Russian Federation, President 2020). The youth in the Arctic represent an important potential source of labour in implementing the planned large-scale investment projects.

The population of the Russian Arctic zone is largely urban: 89 per cent of the population live in cities, but the proportion of youth in the population is 6 per cent lower than the national average (Statistics Russia 2018). In this chapter we discuss the problems arising from a lack of young people in Arctic industrial cities. Most of the cities are of the single-industry type ("monocities"), meaning that they were built during the Soviet Union to host the workforce needed to extract or process the natural resources of the Arctic. Today, a significant proportion of the cities have the status of "being in the most difficult social and economic situation" or "facing risks of a worsening of the social and economic situation" (Government of the Russian Federation 2014a). What is more, only 22.3 per cent of all Russian 
monocities demonstrate sustainable development, defined in this research as "a shifting process in which resource exploitation, redistribution of investments and technological development go in harmony with social wellbeing and environmental balance, providing added value to both current and future potential" (Statistics Russia 2018).

As noted by Mart'ianov (2013, p. 125), in Russia "almost all northern Arctic settlements are artificially created monocities, which makes them vulnerable in the open economy". The single-industry style of urban development makes it difficult to diversify the range of citizens' activities and to increase options for developing labour markets, education and leisure. The variety of leisure activities for young people in such communities is limited compared to that found in large cities and regional centres (Monogoroda Arkticheskoi zony RF 2016). This may be one of the main reasons for the outflow of the population from monocities and, in particular, offer a compelling reason of why young adults leave them. Studies of Arctic monocities reveal that they "predominantly show a regression in demographic indicators: there is a negative population dynamic, the migration outflow is increasing and only a quarter of the cities have recorded a natural population growth" (Statistics Russia 2018).

The statistical indicators characterizing the youth as a social group in the regional communities offer insights into the problem. According to the Russian government, young people in Russia are defined as those aged between 14 and 30 years (Government of the Russian Federation 2014b). Their proportion in terms of the total population of the Russian Arctic is 13.8 per cent on average, compared with 19.3 per cent in the Russian Federation as a whole (Figure 1.1). It is only in the Arctic zone of the Republic of Sakha (Yakutia), Krasnoyarsk Territory and Arkhangelsk Region that as much as one in five residents is a young person. In Murmansk Region and the Yamal-Nenets and Chukotka Autonomous Districts, the

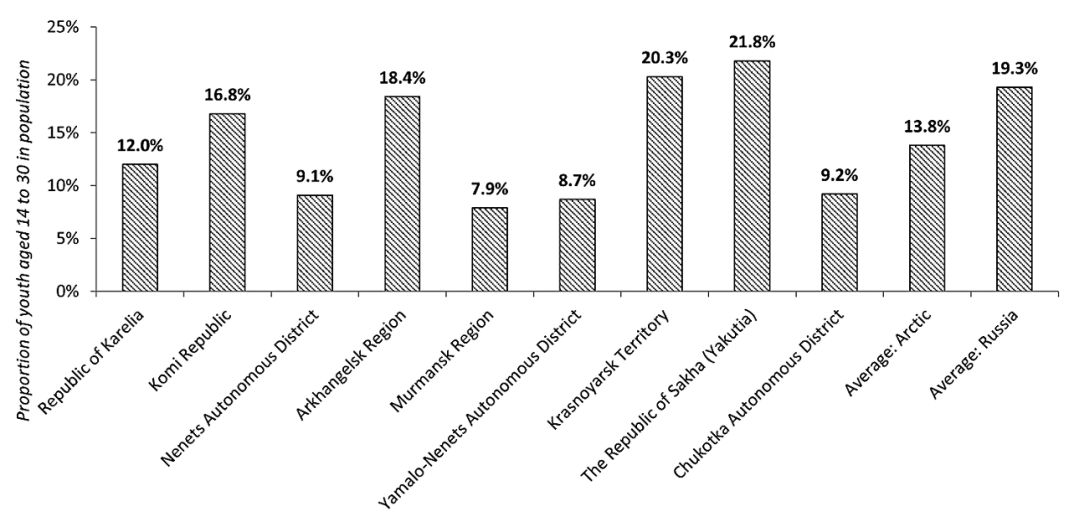

Figure 1.1 Proportion of young people between the ages of 14 and 30 years in the total population of the Russian Arctic regions. 
proportion of young people is significantly lower than in the country as a whole. These regions face a declining birth rate as well as an outflow of youth in pursuit of increased educational opportunities.

The Russian Arctic exhibits a number of specific features, such as harsh climatic conditions, their remoteness from federal or regional centres and a high degree of dependence on single branches of industry (primarily the extractive industries). These may contribute to a high likelihood that young people will leave the regions, given their relatively high levels of mobility. The Russian Arctic experiences intensive migration flows, in terms of both arrival and departure of the population from the region (Fauzer 2016). On the other hand, regardless of their location, youth are the most mobile part of the country's population anywhere, ready to pursue ambitious goals in life. Timothy Heleniak claims, in his paper "Migration in the Arctic", that due to the small size of the population and settlements, migration plays a significant impact on the overall population in the Arctic (Heleniak 2014). The following discussion on broad migration flows is a disaggregation of those flows in terms of the key factors of age, gender and level of education.

Ulrich Beck, the pioneer of the concept of the risk society, noted that society is moving toward a new stage of modernity that produces risks. In his words, a risk is defined as a "systematic way of dealing with hazards and insecurities induced and introduced by modernization itself" (Beck 1992, p. 21). According to Beck, some people are more affected than others by the distribution and growth of social risks. Our research draws on the concept of the risk society to investigate the phenomenon of social risk, which occurs when individuals (young adults) cannot rely on help from state institutions but draw on their own resources and take personal responsibility for risk. Beck's ideas are still widely discussed and criticized. For example, one argument is that Beck's definition of risk is predicated on inconsistent "realism" and "constructivism" (Leiss 1994). It has also been asserted that Beck exaggerates the importance of modern risk, since we now live in safer times (Lupton 1999, p. 184). Yet such critical statements do not diminish the importance of Beck's ideas, since his point of view is original and reflexive; it is expressed in terms of the ability to respond to the acute problems of our time.

According to Zubok, youth generally belong to the most risk-prone groups. Innovations are sometimes risky, and youth is a transitional state in the human life cycle. As Zubok notes,

active interaction (of youth) with new social mediators, its inclusion in the global world, ability to feel, learn and master new emerging social patterns (economic, political, cultural) give it not only dynamism, but also make them the most important driving force for innovative development.

(Zubok et al. 2016, p. 35)

Their innovative potential is in high demand, especially during periods when social and economic systems are developing. When planning the social and 
economic development of strategic territories, it is particularly important to take into account the position of young people as a special social group that will occupy the leading role in driving this development.

Analysis of regional migration flows in Russia's Arctic has shown a decrease in the population of young people in the majority of regions, with the exceptions being Krasnoyarsk Territory, Yamal-Nenets Autonomous District and Murmansk Region. Most people leave for another region of the Russian Federation, whereby this can be considered mainly an interregional flow (Table 1.1). One in three people leaving the Arctic and one in three entering it is a young person between the ages of 14 and 30. Many young people are leaving their native Arctic towns; on the other hand, however, many are also coming to the Arctic. These flows partially compensate each other in quantitative terms but do not have a significant effect on the resident population in the region, since migration is also high among the elder population.

According to Mkrtychian, most people migrate between the ages of 17 and 19 years graduating from upper secondary school. The main reason for youth migration at this age is the search for educational opportunities and professional self-realization (Mkrtychian 2015).

This introduction to the issues may be summarized in the following observations:

- the Arctic is experiencing a decline in population;

- the Arctic has the most mobile population in Russia;

- youth are underrepresented in the population of the Russian Arctic; and

- youth are the most mobile part of the Arctic population.

These points suggest that measures should be developed for retaining youth in Arctic industrial cities. Indeed, the future development of the Arctic regions depends largely on the young generation's perception of their own prospects and their choice about whether or not to leave these regions. However, research to date has largely overlooked these perceptions and choices, which are the most important considerations for the future of the Russian Arctic

\section{Methods and materials}

To answer the question, "Would you prefer to live and work here in the North or to leave?", we conducted a sociological survey as part of a larger research effort studying youth wellbeing in Arctic industrial cities; the study used both qualitative and quantitative approaches. The main goal of the research was to assess perceptions of wellbeing and prospects for the future among young people living in Arctic monocities. The survey sought to identify the general motivation, attitudes and values of youth regarding life, training and work. We invited youth to participate in the survey only in Arctic monocities. Our sample sites were: 
Table 1.1 Youth mobility by region in the Russian Arctic, 2018

\begin{tabular}{|c|c|c|c|c|c|}
\hline Region & $\begin{array}{l}\text { Youth migration } \\
\text { surplus in all } \\
\text { migration types } \\
\text { (intraregional, } \\
\text { interregional and } \\
\text { international) }\end{array}$ & $\begin{array}{l}\text { Youth migration } \\
\text { surplus in } \\
\text { interregional } \\
\text { migration }\end{array}$ & $\begin{array}{l}\text { Share of } \\
\text { interregional } \\
\text { migration in total } \\
\text { youth outflow for } \\
\text { all types of } \\
\text { migration }(\%)\end{array}$ & $\begin{array}{l}\text { Share of youth of } \\
\text { total number of } \\
\text { those migrated } \\
\text { interregionally } \\
(\text { those who left }) \\
(\%)\end{array}$ & $\begin{array}{l}\text { Share of youth of } \\
\text { total number of } \\
\text { those migrated } \\
\text { interregionally } \\
\text { (arrivals) (\%) }\end{array}$ \\
\hline Republic of Karelia* & -141 & -135 & 46.7 & 40.2 & 37.6 \\
\hline Komi Republic* & -642 & -557 & 85.7 & 27.4 & 30.9 \\
\hline Krasnoyarsk Territory* & 594 & 301 & 72.7 & 32.1 & 37.6 \\
\hline Republic of Sakha (Yakutia)* & -147 & -26 & 28.9 & 32.0 & 34.6 \\
\hline Arkhangelsk Region* & -409 & -1401 & 45.1 & 33.1 & 36.6 \\
\hline Nenets Autonomous District & -114 & -124 & 47.9 & 36.3 & 32.2 \\
\hline Murmansk Region & 624 & 275 & 63.1 & 31.7 & 38.4 \\
\hline \multicolumn{6}{|l|}{ Yamalo-Nenets Autonomous } \\
\hline District & 253 & 292 & 65.6 & 31.7 & 35.2 \\
\hline \multicolumn{6}{|l|}{ Chukotka Autonomous } \\
\hline District & -126 & -116 & 78.3 & 29.0 & 31.1 \\
\hline \multicolumn{6}{|l|}{ Total, Russian Arctic / } \\
\hline Average, Russian Arctic & -108 & -1491 & 61.6 & 32.6 & 34.9 \\
\hline
\end{tabular}

* For regions whose territory belongs to the Arctic in part, data are indicated only for the Arctic territories of these regions. 
- Novy Urengoy, Yamal-Nenets Autonomous District, "the gas capital of Russia", which stands out from other Russian cities by virtue of its sustained economic growth and economic prosperity (Stammler and Eilmsteiner-Saxinger 2010; Men'shikov 2015);

- Neryungri, Republic of Sakha (Yakutia), one of the monocities classified by the government as "undergoing risks of a worsening of the social and economic situation" (Government of the Russian Federation 2014a); and

- Kirovsk, Murmansk Region, characterized as a municipality "having the most difficult social and economic situation" (ibid.).

As the list indicates, Neryungri and Kirovsk are on the negative end of the scale compared to Novy Urengoy in terms of social and economic indicators (see also Ivanova et al., this volume, for a comparison of youth policy implementation in these same cities).

All respondents to the survey were between 14 and 30 years of age, thus falling within the definition of "youth" in Russian law (Government of the Russian Federation 2014b; Kekkonen et al. 2017). Since young people as a social group are heterogeneous, it was necessary to include both studying and working young people, reflecting their particular situation at different stages of growing up and becoming an individual socially and professionally. The lower age limit of 14 years is characterized by the emergence of physical maturity and of rights and social responsibilities. The upper limit of 30 years corresponds to economic independence and professional and personal stability (Kozhurova 2012). The diversity of views and perceptions among young people as an age group has been confirmed in qualitative research carried out by colleagues in the same project Their findings indicate that the same variable can function as an incentive to leave a city among school-age youth, but contribute to its attractiveness as a place to realize one's aims in life for young adults having or wanting to establish a family.

The sample for the survey drew on a stratified random selection, with gender in addition to age employed as principal segmentation factors. A total of 436 people took part in the survey. To understand the full picture of the survey, we present below the age distribution of the youth of the focal towns who took part in the study (Figure 1.2).

Of the total number of respondents, $45.4 \%$ were residents of Novy Urengoy, $42 \%$ residents of Neryungri, and $12.6 \%$ residents of Kirovsk; that is, the sample is distributed approximately equally between the "crisis" towns and the prosperous town. The reasons for the different classifications are set out at the federal level (Government of the Russian Federation, 2014a).

In addition to the quantitative survey, our results reflect insights from detailed in-depth interviews, focus group discussions and participant observation with young people in all three case cities. The data were complemented by conversations with experts in the municipalities and industrial companies responsible for youth, staff development and social responsibility. 


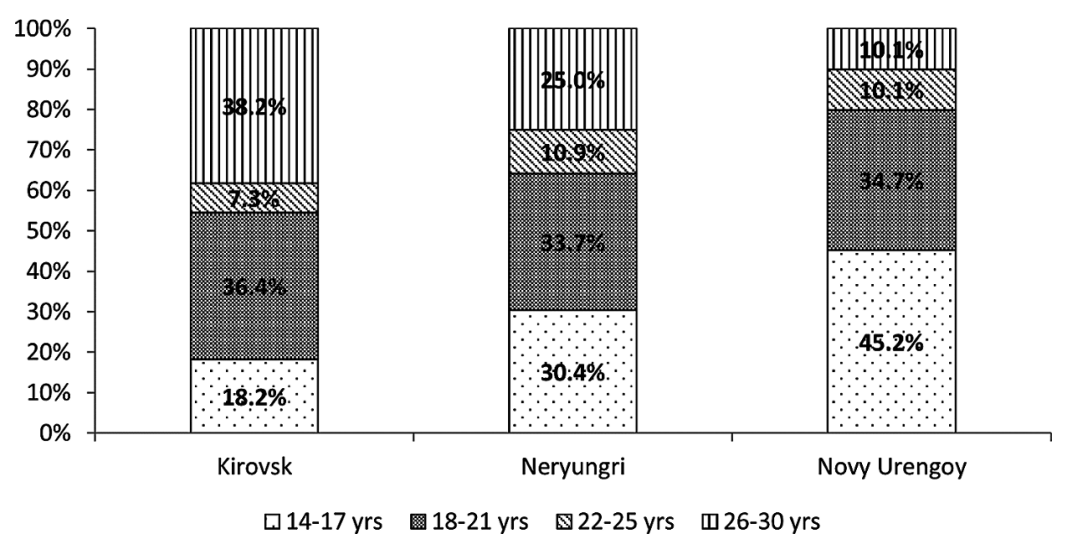

Figure 1.2 Respondents' age distribution in the three case towns (per cent).

\section{Discussion of results}

\section{Young people's feelings about migration in the Arctic industrial towns}

The results of our survey suggest that the basic values among youth in our Arctic monocities are material security ( $90.9 \%$ of respondents), a strong family and the opportunity to unlock one's personal potential ( $87.3 \%$ of respondents for each). These figures suggest that the extent to which young people see these cities as environments supporting these values will influence any consideration they give to migrating. However, decision-making often happens on a far finer-grained level. In this section we present some findings reflecting that level, our purpose being to develop a clearer understanding of what constitutes wellbeing for youth in an Arctic industrial city. Young people's interest in migrating most often relates to their educational opportunities and professional self-realization. This decision directly affects the life of a young person and the spatial distribution of human capital in general (Kashnickii et al. 2016). Correspondingly, an individual young person's feelings regarding migration will differ depending on the stages of his or her social development.

Most of the youth in the Arctic industrial towns have considered leaving their hometown: $68.5 \%$ would like to leave; another $13.5 \%$ would like to leave, but thus far have had no opportunity; and only just under one-fifth $(18 \%)$ plan to stay. If we consider the current situation with reference to the age groups of young people, interest in migration is strongest between the ages of 14 and 21 (Figure 1.3) and most often relates to educational opportunities. According to Mkrtychian, the ages between 15 and 19 represent a peak in migration activity (Mkrtychian 2017, p. 225).

Where education as a reason to leave is concerned, the difference between cities can also be explained by the fact that there is one educational organization in Kirovsk offering secondary vocational education programmes, while Novy Urengoy and Neryungri both have three such organizations. Neryungri has a branch of North Eastern Federal University in Yakutsk where students 


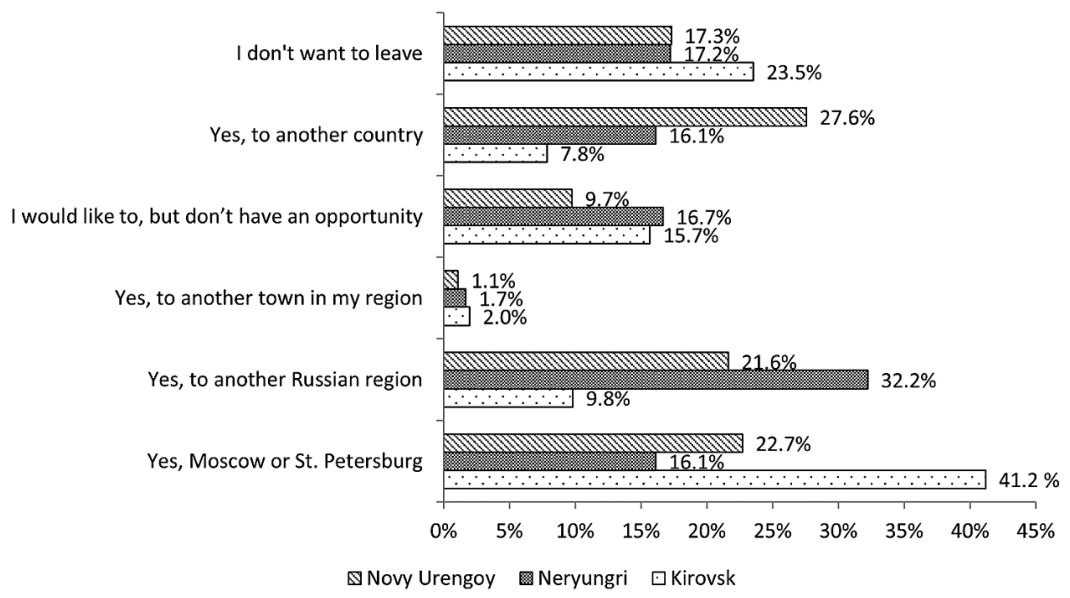

Figure 1.3 Youth attitudes toward migration in Arctic monocities, per cent by monocity, per cent by age group.

can obtain a higher education, for the most part in technical fields. In Novy Urengoy, branches of universities were closed due to their poor quality and the poor reputation of the qualifications they award. In Kirovsk, youth do not have to move to get a higher education, as the neighbouring town Apatity, within half an hour by bus, has two branches of universities in Murmansk, as well as the Kola Science Centre of the Russian Academy of Sciences. Apatity has a more vibrant student life than Kirovsk, and some students want to move there; however, this does not qualify as a significant instance of outmigration, as both towns are geographically and economically related to each other. Many of the youth organizations operate in both cities, and young people move back and forth frequently, sometimes several times a day (see also Bolotova, this volume).

Another salient consideration is that the number of people of reproductive age is shrinking. This poses a threat to the reproduction of human capital in Arctic (post-)industrial towns when educational migrants do not return to their native region after graduation (Andreenkova 2010). We call this the uncompensated aspect of educational migration. For young people in the (post-)industrial Arctic towns, large metropolitan areas and even foreign countries are more attractive than home: such larger communities are magnets in providing extensive educational services as well as a higher standard of living, even though some respondents were aware that housing and other services are more expensive there (Figure 1.4).

By the time most young people already have a professional education (between the ages of 22 and 25), the proportion of those who focus on other regions of Russia increases, or inclinations to migrate turn into "conscious" desires, such as "I want to move, but I don't have an opportunity to do so." In the age range of 26 to 30 years, the share of those who do not want to leave increases sharply, to approximately one in four respondents. 


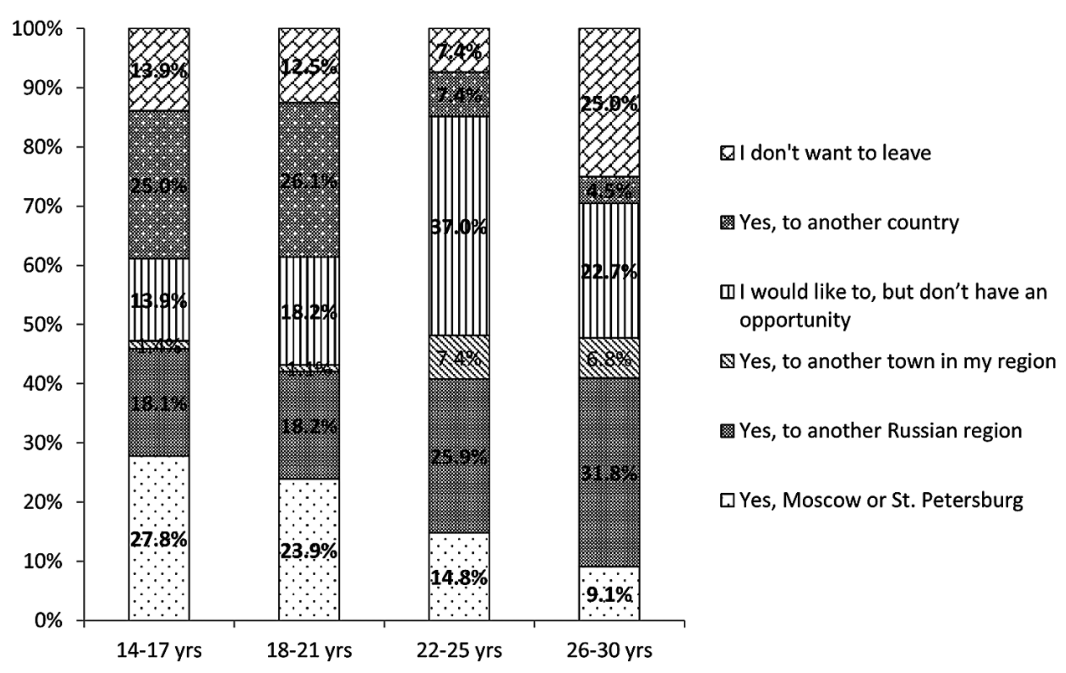

Figure 1.4 Youth attitudes toward migration in Arctic monocities, per cent by monocity, per cent by age group.

Every second young adult notes that in another region there is an opportunity to find an interesting job (49.7\%), get a higher salary than in their native region $(40.7 \%)$, continue their studies and professional development $(40.7 \%)$ or just to see the world (44.7\%).

In light of the qualitative research, some of the differences between the case cities become more easily understood. For example, almost all of our survey respondents in Kirovsk have had contact with foreigners at some point in their life and also travel frequently to Moscow and St. Petersburg. The city positions itself as a tourist centre in addition to being a mining town, and receives both Russian and foreign tourists during the winter season. Moreover, the nearby Kola Science Centre has long had extensive international contacts and visitors, as has the local research station maintained in the mountains near Kirovsk by Moscow State University. Contact with outsiders is something normal and part of everyday life and work. In comparison to Neryungri and Novy Urengoy, Kirovsk also has a much longer history, one starting in the 1920s rather than the 1970s. We hypothesize that the reasons why fewer people want to leave Kirovsk include its less isolated geography and its better-embedded local patriotism. Among those who intend to leave, Moscow and St. Petersburg are the most logical destinations, being only a 90-minute flight or a day's drive away.

Perhaps more frequent travel to Finland and more first-hand experience abroad as individual travellers without tourist or education programmes has also contributed to the youth in Kirovsk being more realistic about the prospects of life in another country. Only $8 \%$ of the respondents from Kirovsk aspired to live in another country; the figure for Neryungri was double this, and for Novy Urengoy almost triple. 
In Murmansk Region in general, and in Kirovsk in particular, travel abroad is often not for leisure, but related to work or income: many people travel to Finland to work picking berries in summer and do seasonal work in the tourism industry in winter. Moreover, they travel to Finland to shop during sales and buy quality goods at cheaper prices than in Russia. By contrast, travel abroad in Novy Urengoy is often related to leisure or personal development. With their higher salaries from the local gas industry, inhabitants of this city are often able to afford expensive holidays already at a rather young age. They travel abroad in a more luxurious manner and live, eat and entertain themselves more expensively. Indeed, before the crisis of 2014, in the northern Finnish ski resorts one could often hear the phrase "Gazprom is coming", meaning a great deal of revenue was to be had from rich Russian tourists during the winter holiday season. In somewhat of a simplification, one could say that inhabitants of Kirovsk travel to northern Finland to serve inhabitants of Novy Urengoy spending their holidays there at the ski resorts.

In addition, Novy Urengoy has numerous gas company-sponsored partnerships with German cities, especially its twin city, Kassel. There are frequent school exchanges at the secondary level, as well as regular video conferences linking students in Novy Urengoy and Germany. For the most part these are extremely well-organized programmes giving Russian children the opportunity to travel to Germany. In this light, it may be easier to understand why more youth from Novy Urengoy than from Kirovsk might wish to live abroad, since the latter have encountered fewer affluent foreigners at home or abroad.

On balance, we can interpret the survey results as indicating that the leisure-oriented travel abroad of Novy Urengoy inhabitants, along with the schoolchildren's travel and interaction with elite schools sponsored by the gas company, creates an image of living abroad as being easier, more comfortable and more luxurious than in Russia. In comparison, for inhabitants of Kirovsk, living abroad is associated more with hard work and therefore may not be a particularly desirable dream for youth to pursue.

\section{Factors affecting an inclination to migrate and wellbeing among youth}

Intentions that young people may have to migrate are formed under the influence of both external and internal factors. In this section, we argue that migratory moods, or intentions, also tell us about young people's senses of wellbeing when living in a northern industrial city: the greater one's sense of wellbeing in one's current residence, the less impetus exists for making the effort to migrate. Young people represent a social group which, due to its high mobility and ambition, may not yet have put down roots in a specific place, making the decision to move easier for them. Aliev considers migration flows the most visible and easily identifiable manifestation of the general level of wellbeing of a town or a region (Aliev 2012, p. 54). Flows go consistently from less prosperous territories to more prosperous ones. According to Russian studies, the main reasons for the outflow of young people from small 
towns are low incomes, narrow, sector-specific labour markets and other social and economic problems intrinsic to the periphery. However, these disadvantages are tempered by the particular circumstances in the Arctic industrial cities, where the level of income is much higher than in other small cities of the country. Employees in industrial companies can often anticipate receiving a higher salary in the Arctic than they would get for similar work in St. Petersburg or Moscow. This shows that money may not be the main driving force for migration in these cases.

More so than money, life satisfaction is one of the integral and complex indicators for assessing wellbeing. It may include satisfaction with one's position in society, financial situation and other achievements (Andreenkova 2010). In general, much social science research has considered life satisfaction as almost synonymous with wellbeing.

We proceeded to carry out a factor analysis to assess the young people's migration plans. The sociological significance of applying factor analysis is to compress the data set into a matrix that reflects the same information, but with fewer variables. This analysis is based on the premise that variables are indirect manifestations of a small number of latent factors (Nivorozhkina 2008).

\section{Three dimensions of wellbeing: towards defining criteria}

We acknowledge that from a qualitative point of view, more in-depth information uncovers the deeper meanings of each of these factors for the youth in our case cities. Most importantly, "satisfaction with wellbeing" is such a broad concept that a limited set of factors cannot possibly grasp the diversity of worldviews and approaches subsumed under it. Cultural research on wellbeing has demonstrated this diversity and identified the lack of clarity of wellbeing as an analytical concept (cf. Stammler and Toivanen, this volume).

Our list of factors is an attempt to categorize some of the indicators that would be related to broader notions of wellbeing in general, including social and economic considerations.

We suggest subsuming youth's satisfaction with their personal economic situation under the larger heading of "financial considerations", which includes the following indicators: income level, living conditions, guarantee of obtaining one's desired job and, as a result, confidence in a prosperous future (Table 1.2). Young people's interest in high salaries and maximum realization of their professional competencies is obvious, since salaries are the main source of income for a modern person, providing most of his or her daily needs: "[Salary] is a measure of society's assessment of the significance, value and prestige of labour" (Konstantinovskii et al. 2013). However, we do not claim that personal finances are the only, or always the principal, factor determining a young person's decision to live in or leave northern industrial cities.

The second group of indicators relates to the social sphere, under which we subsume "satisfaction with leisure and rest", "health", "quality of health care" and "environmental situation". Moreover, "satisfaction with one's 
Table 1.2 Understanding wellbeing: from indicators to dimensions

\begin{tabular}{|c|c|c|c|c|}
\hline Factors & 1 & 2 & 3 & 4 \\
\hline $\begin{array}{l}\text { Satisfaction with one's life in } \\
\text { general }\end{array}$ & 0.355 & 0.104 & 0.766 & 0.035 \\
\hline Satisfaction with income & 0.824 & 0.197 & 0.035 & -0.091 \\
\hline $\begin{array}{l}\text { Satisfaction with standard of } \\
\text { living }\end{array}$ & 0.719 & 0.312 & 0.153 & 0.079 \\
\hline $\begin{array}{l}\text { Employabilityl guarantee of } \\
\text { employment }\end{array}$ & 0.86 & 0.232 & -0.0006 & -0.127 \\
\hline Certainty in the future & 0.728 & 0.39 & 0.174 & -0.001 \\
\hline Satisfaction with leisure activities & 0.173 & 0.799 & 0.227 & -0.061 \\
\hline Satisfaction with wellbeing & 0.261 & 0.788 & 0.108 & 0.124 \\
\hline $\begin{array}{l}\text { Satisfaction with the medical care } \\
\text { system }\end{array}$ & 0.345 & 0.708 & -0.101 & 0.017 \\
\hline Satisfaction with ecology & 0.259 & 0.751 & 0.035 & -0.229 \\
\hline Level of happiness & -0.079 & 0.066 & 0.873 & -0.057 \\
\hline Gender & -0.076 & -0.054 & -0.029 & 0.975 \\
\hline
\end{tabular}

Note: Value for Kaiser-Mayer-Olkin sample adequacy after the final selection of observations: 0.858 (more than 0.5 )

social surroundings", meaning relatives, neighbours, co-dwellers in the city, peers in school and at work, has an important impact on senses of wellbeing. We argue that a high value for this factor shows young people's confidence in their social wellbeing and sense of security.

We assign the last indicator "emotional satisfaction and level of happiness with one's life" to the mental sphere, on the most personal level.

For young people in Arctic monocities, wellbeing comprises financial, social and mental determinants. Together, these contribute to a sense of security and stability that may encourage an adult to stay in the North. In the present case, a look at the current situation in the three cities shows that young people rely on their own feelings of wellbeing. Clearly, wellbeing in Arctic monocities is also influenced by policy at both the federal and regional levels, the existing and potential conditions for social and economic development of the towns, the attitude of the local authorities, the business climate and the community. However, it is necessary to have a clearer understanding of those individuals on whose wellbeing we are focusing. When young people see their Arctic towns as providing opportunities to meet needs associated with their basic values (satisfaction with income level, certainty about the future, satisfaction with leisure), they may be less inclined to leave.

In light of the above, we suggest that place-based dimensions of wellbeing should be considered in analysing the feelings of youth in Arctic industrial cities regarding migration. Factors influencing such sentiments should serve as the basis for developing recommendations on improving youth policy at the national and regional levels, with the aim being to "keep" young people in the Arctic and thus ensure viable development of the region. 


\section{Conclusion}

This chapter has outlined a relation between dimensions of wellbeing and intentions to migrate among young people in Russian Arctic industrial towns. The conditions in such industrial cities are often considered less favourable than in other places in the country. We have argued that the combination of five structural factors that influence the development of such cities and are characteristic of young people in general may increase youth outmigration from such cities: the Arctic is experiencing a decline in population, although its strategic importance has increased and industry is still developing there. There are fewer young people in the Arctic than elsewhere, a situation exacerbated by the fact that the Arctic has the most mobile population in Russia, and youth are the most mobile part of the population in general. On the other hand, youth are the most innovative part of the population and are more willing to take risks than other age groups. In this light, given the need for development in the Arctic, there is a corresponding need to keep youth in Arctic industrial cities. We have argued here that if the views of young people on their own wellbeing (satisfaction with income level, certainty about the future, satisfaction with leisure) are not taken into consideration in strategic planning in such cities, in many cases an inclination on their part to migrate may translate into outmigration.

We conducted a survey on youth wellbeing in three Arctic monocities Kirovsk, Novy Urengoy and Neryungri. Qualitative fieldwork in the cities then validated the observations made on this basis as well as their contextsensitive interpretation.

Our research results show that youth in Arctic industrial towns express an interest in migrating. Yet respondents' narratives, as well as survey data, suggest that young people do not necessarily act on their intentions to migrate, especially when they perceive the conditions in their hometown for their social, financial and mental wellbeing as being favourable. Given the strategic importance of Arctic industry for the Russian economy, the issue of preserving or increasing the population in Arctic cities is particularly relevant. We argue that some of these cities may have a future, even when they run out of the mineral resources they were built to extract, if youth see them as enabling the dimensions of wellbeing better than other locations. Some of the cities, such as Kirovsk, have already started to diversify their economy. Relevant reforms which need active young people for their implementation are being carried out.

A policy of keeping youth in a particular community should be based on the development of existing and the creation of new economic and social incentives geared to enhancing the factors that promote youth wellbeing. If the social environment of the Arctic region continues to become more satisfying and people-centred, Arctic industrial cities can compete favourably with other cities for the best, most innovative and most creative people, who will be crucial in driving development. 


\section{References}

Aliev, P. R. (2012) 'Vliianie migratsii na trudovoi potentsial molodezhi regiona', Sovremennye issledovaniia sotsial'nykh problem, 12, pp. 54-68.

Andreenkova, N.V. (2010) 'Sravnitel'nyi analiz udovletvorennosti zhizn'iu i opredeliaiushchikh ee faktorov', Monitoring obshchestvennogo mneniia, 5, pp. 189-215.

Beck, U. (1992) Risk society: Towards a new modernity. London: SAGE publications. Bolotova, A. (this volume) 'Leaving or staying? Youth agency and the livability of industrial towns in the Russian Arctic', in Stammler, F. and Toivanen, R. (eds) Young people, wellbeing and placemaking in the Arctic. London: Routledge, pp. 53-76.

Fauzer V. V. (2016) Demograficheskie i migratsionnye protsessy na rossiiskom Severe: 1980-2000. Syktyvkar: Izd-vo SGU im. Pitirima Sorokina.

Government of the Russian Federation (2014a) O perechne monoprofil'nykh munitsipal'nykh obrazovanii Rossiiskoi Federatsii (monogorodov). Available at: https://base.garant.ru/70707138/ (Accessed: April 25 2020).

Government of the Russian Federation (2014b) Osnovy gosudarstvennoi molodezhnoi politiki Rossiiskoi Federatsii na period do 2025 goda. Available at: http://government.ru/docs/15965/ (Accessed: March 17 2021).

Heleniak, T. (2014) Migration in the Arctic. Arctic yearbook. Available at: https://arcticyearbook.com/images/yearbook/2014/Scholarly_Papers/4.Heleniak.pdf (Accessed: April 25 2020).

Ivanova, A., Oglezneva, T. and Stammler, F. (this volume). 'Youth law, policies and their implementation in the Russian Arctic', in Stammler, F. and Toivanen, R. (eds) Young people, wellbeing and placemaking in the Arctic. London: Routledge, pp. 147-169.

Kashnickii, I.S., Mkrtychian, N.V. and Leshukov, O.V. (2016) 'Mezhregional'naia migratsiia molodezhi Rossii: Kompleksnyi analiz demograficheskoi statistiki', Voprosy obrazovaniia, 3, pp. 169-203.

Kekkonen, A.L., Simakova, A.V. and Stepus', I.S. (2017) 'Osobennosti prostranstvennogo razvitiia i rasshirennoe vosproizvodstvo chelovecheskogo kapitala v Respublike Kareliia i arkticheskikh regionakh Evropeiskogo severa Rossii', Mir ekonomiki i upravleniia, 17 (2), pp. 86-96.

Konstantinovskii, D.L., Voznesenskaia, E.D. and Cherednichenko, G.A. (2013) 'Rabochaia molodezh' segodnia: Obrazovanie, professiia, sotsial'noe samochuvstvie', Sotsial'naia nauka i sotsial'naia praktika, 2, pp. 21-38.

Kozhurova, A.A. (2012) 'Demograficheskoe povedenie molodezhi regionov severovostoka Rossii', Sotsial'naia sfera, 16, pp. 60-64.

Leiss, W. (1994) Review of Ulrich Beck. Risk society, towards a new modernity. Available at: http://www.ualberta.ca/ cjscopy/articles/leiss.html (Accessed: April 25 2020).

Lupton, D. (1999) Risk. London: Routledge.

Mart'ianov, V.S. (2013) 'Strategiia gorodskogo razvitiia v Arkticheskom regione Rossii', EKO, 5, pp. 124-138.

Men'shikov, A. (2015) 'Gazovaia stolitsa: ot poselka geologov - Do samogo perspektivnogo goroda Iamala', Rossiiskaia gazeta-spetsial'nyi vypusk, 140. Available at: https://rg.ru/2015/06/30/reg-urfo/gaz.html. (Accessed: April 25 2020).

Mkrtychian, N.V. (2015) 'Vozrastnaia struktura naseleniia Rossii i ee vliianie na vnutrenniuiu migratsiiu', Nauchnye trudy: Institut narodnokhoziaistvennogo prognozirovaniia $R A N, 13$, pp. 209-221.

Mkrtychian, N.V. (2017) 'Migratsiia molodezhi iz malykh gorodov Rossii', Monitoring obshchestvennogo mneniia, 1, pp. 225-242. doi: 10.14515/monitoring.2017.1.15. 
Monogoroda Arkticheskoi zony RF: problemy i vozmozhnosti razvitiia: analiticheskii doklad (2016) Available at: http://www.arcticandnorth.ru/Encyclopedia_Arctic/ monogoroda_AZRF.pdf (Accessed: April 25 2020).

Nivorozhkina, L.I. (2008) Mnogomernye statisticheskie metody v ekonomike. Rostov n/D: Nauka-Spektr.

Russian Federation, President. (2020) Ukaz Prezidenta $R F$ 'O Strategii razvitiia Arkticheskoi zony Rossiiskoi Federatsii i obespecheniia natsional'noi bezopasnosti na period do 2035 goda'. Available at: https://www.garant.ru/products/ipo/prime/ doc/74710556/ (Accessed: March 2 2021).

Stammler F. and Eilmsteiner-Saxinger G. (2010) Biography, shift-labour and socialisation in a northern industrial city - The far North: Particularities of labour and human socialisation. 2nd edited version. Rovaniemi: Arctic Centre. Available at: http://urn. fi/URN:NBN:fi:ula-201111221215

Stammler, F. and Toivanen, R. (this volume). 'The quest for a good life: Contributions from the Arctic towards a theory of wellbeing', in Stammler, F. and Toivanen, R. (eds) Young people, wellbeing and placemaking in the Arctic. London: Routledge, pp. 1-13.

Statistics Russia (2018) Otsenka chislennosti postoiannogo naseleniia sukhoputnykh territorii Arkticheskoi zony Rossii na 1 ianvaria 2018 goda. Available at: http://www. gks.ru/free_doc/new_site/region_stat/calendar1-2019.htm (Accessed: April 25 2020).

Zubok, U.A., Rostovskaia, T.K. and Smakotina, N.L. (2016) Molodezh' i molodezhnaia politika v sovremennom rossiiskom obshchestve. Moscow: ITD «Perspektiva». 